\title{
Hubungan Pengetahuan, Tingkat Pendidikan, Sumber Informasi, dan Pola Asuh dengan Pernikahan Dini pada Wanita
}

\author{
Tri Indah Septianah, Tetti Solehati*, Efri Widianti \\ Fakultas Keperawatan Universitas Padjajaran, Jatinangor, Kabupaten Sumedang 45363, Indonesia \\ tetti.solehati@unpad.ac.id* \\ * corresponding author
}

ARTICLE INFO

Keywords

Early marriage

Education level

Information source

Knowledge

Parenting style

\begin{abstract}
Early marriage is a problem that becoming world's attention because of the high incidence rate and it is not resolved yet. Some of the factors that causes early marriage are knowledge, education levels, informations source and parenting style. This study aims to determine the relation between knowledge, education levels, informations source, and parenting style with early marriage so this study can reduce the bad impacts of early marriage. This study use a descriptive correlational method with case control approach. The population in this study is woman who were married on 2018 with ratio sample case with control is $1: 1$ and use simple random sampling. Data will be analyzed using univariate (descriptive) and bivariate (Chi-square and Spearman) analysis. The results of the study showed that there is a difference between knowledge of the respondents who does early marriage with respondents who does not doing early marriage $(p=0,000)$, that there is a difference between education levels of the respondents who does early marriage with respondents who does not doing early marriage $(p=0,000)$, that there is a difference between informations source of the respondents who does early marriage with respondents who does not doing early marriage $(\mathrm{p}=0,000)$, that there is a difference between parenting style of the respondents who does early marriage with respondents who does not doing early marriage $(\mathrm{p}=0,000)$. There is a relation between knowledge, education levels, informations source, and parenting style with early marriage.
\end{abstract}

\section{Pendahuluan}

Pernikahan adalah suatu tahapan penting dalam kehidupan manusia. Untuk itu, diperlukan kesiapan yang matang sebelum melaksanakan pernikahan. Dewasa ini, sering terjadi pernikahan dini yang dianggap kurang baik bagi masyarakat. Pernikahan dini dianggap sebagai pernikahan yang dilakukan terlalu awal dan tanpa persiapan yang matang baik dari segi fisik, mental, ekonomi, dan lainnya. Menurut Badan Kependudukan dan Keluarga Berencana Nasional (BKKBN), pernikahan dini adalah pernikahan yang dilakukan secara tidak sehat. Pernikahan yang sehat dimaksudkan pernikahan yang dilakukan pada usia minimal 25 tahun untuk laki-laki dan 20 tahun untuk wanita. Hal tersebut dipertimbangkan atas dasar pentingnya kematangan sistem reproduksi dalam sebuah pernikahan [1].

Secara global, untuk saat ini lebih dari 700 juta perempuan di dunia melakukan pernikahan di bawah usia 18 tahun, dan 250 juta diantaranya bahkan melakukan pernikahan di usia kurang dari 15 tahun. Di Indonesia sendiri, pernikahan usia dini mengalami penurunan dari tahun 2008 
sebanyak 27,4\% menjadi $23 \%$ pada tahun 2015. Namun, hal tersebut masih dianggap tinggi oleh Badan Pusat Statistik [1].Indonesia menjadi salah satu negara dengan kejadian pernikahan dini yang tinggi dengan persentase 34\%. Hal tersebut menjadikan Indonesia berada di urutan ke 37 dari 158 negara di dunia dengan kejadian pernikahan usia dini. Sedangkan di Asia Tenggara sendiri, menurut data dari Association of South East Asia Nations (ASEAN) Indonesia menempati urutan kedua setelah Kamboja dengan kejadian pernikahan usia dini yang tinggi [3]. Jawa Barat adalah salah satu provinsi dimana setengah dari kabupaten dan kecamatan memiliki prevalensi kejadian pernikahan dini dibawah rata-rata nasional, namun masih terdapat kecamatan-kecamatan dengan prevalensi kejadian pernikahan dini yang sangat tinggi.Salah satu kecamatan dengan prevalensi pernikahan dini diatas rata-rata nasional $(25 \%)$ yaitu kecamatan Tanjungsari yang berada di Kabupaten Sumedang dengan persentase 32\% [1].

Menurut Kantor Urusan Agama (KUA) Kecamatan Tanjungsari, pada tahun 2018 sebanyak $33,16 \%$ perempuan melakukan pernikahan dibawah usia 21 tahun. Pernikahan dini menjadi masalah di Kecamatan Tanjungsari karena memiliki banyak dampak negatif diantaranya adalah perceraian dan kekerasan dalam rumah tangga. Sebagian besar pelaku pernikahan dini di Kecamatan Tanjungsari berakhir pada perceraian, dan juga tidak jarang perempuan yang menikah dini menjadi korban kekerasan dalam rumah tangga. Dampak negatif tersebut dimungkinkan karena kurang matangnya emosi pada pelaku pernikahan dini. Selain itu, berdasarkan data yang didapatkan dari RSUD Sumedang dikatakan bahwa kasus kanker serviks selalu meningkat setiap tahunnya. Pada tahun 2014 sebanyak 71 kasus, tahun 2015 sebanyak 135 kasus, dan tahun 2016 sebanyak 152 kasus. Sebagian besar pasien dengan kasus kanker serviks memiliki riwayat melakukan hubungan seksual di usia $<20$ tahun. Hal tersebut menunjukkan bahwa wanita yang menikah dini memiliki resiko untuk terkena kanker serviks [4], dimana Kecamatan Tanjungsari merupakan kecamatan dengan angka pernikahan dini yang tinggi di Sumedang.Kepala Dinas Pengendalian Penduduk dan Keluarga Berencana (DPPKB) Kabupaten Sumedang juga mengatakan bahwa pernikahan dini menjadi penyebab rumah tangga hancur di Kabupaten Sumedang. Selain itu, gizi buruk juga terjadi pada anak dari ibu yang menikah dini. Hal ini menunjukkan hingga saat ini kejadian pernikahan dini di Kecamatan Tanjungsari belum bisa teratasi.

Berdasarkan uraian dampak pernikahan dini diatas, sebagian besar dampak negatif yang ditimbulkan dari pernikahan dini terjadi pada wanita. Begitupun yang terjadi di Kecamatan Tanjungsari yang mana wanita lebih terkena dampak pernikahan dini. Oleh karena itu, peneliti menjadikan wanita sebagai subjek dalam penelitian ini.

Pernikahan dini merupakan suatu masalah yang disebabkan oleh faktor dari berbagai bidang. Beberapa faktor yang diyakini sebagai penyebab pernikahan dini diantaranya faktor kebutuhan baik biologis ataupun psikologis, adat, ekonomi, pengetahuan, tingkat pendidikan, sumber informasi dan pola asuh orang tua [4].

Pengetahuan merupakan hasil pengamatan terhadap sesuatu yang bersifat tetap. Menurut penelitian Stang (2015), pengetahuan dan pendidikan memiliki hubungan yang bermakna terhadap pernikahan dini. Hal ini juga didukung oleh suatu penelitian yang menyatakan pengetahuan dan pendidikan merupakan salah satu faktor yang mendorong terjadinya pernikahan dini. Remaja dengan tingkat pendidikan yang rendah dan kurang pengetahuan tentang pernikahan dini cenderung akan melakukan pernikahan lebih awal dibandingkan dengan remaja dengan tingkat pendidikan dan pengetahuan yang tinggi [5][6].

Kurangnya informasi tentang pernikahan dini menjadi kemungkinan terjadinya pernikahan dini baik dari keputusan remaja itu sendiri yang mendapatkan dukungan orangtuanya ataupun permintaan orangtua terhadap anaknya untuk cepat menikah. Sesuai dengan fenomena yang terjadi, banyak warga Kecamatan Tanjungsari yang memalsukan usia untuk mendapat izin menikah. Menurut petugas KUA sendiri, masih banyak desa di Kecamatan Tanjungsari yang kurang terpapar informasi baik informasi tentang sistem reproduksi maupun tentang pernikahan dini dan dampaknya.

Menurut beberapa penelitian, kebutuhan biologis atau keinginan untuk cepat mendapatkan keturunan dan kebutuhan psikologis atau keinginan untuk diakui masyarakat menjadi pendorong faktor penyebab pernikahan dini karena tidak diimbangi dengan pengetahuan akan dampak negatif dari pernikahan dini. Ekonomi disebut-sebut sebagai faktor utama penyebab pernikahan dini, 
namun beberapa penelitian menyebutkan bahwa pernikahan dini tidak hanya terjadi pada keluarga rendah tetapi juga terjadi pada keluarga berpenghasilan tinggi. Adat istiadat juga menjadi penyebab terjadinya pernikahan dini. Adat dapat mempengaruhi pola asuh orang tua terhadap anak. Namun, adat tidak bisa diubah sehingga di beberapa daerah pernikahan dini masih terus berlanjut. Namun, sebuah penelitian menyatakan bahwa nilai-nilai budaya tidak berperan terhadap pernikahan dini [7] [8].

Pada dasarnya, suatu masalah dapat dihindari dengan mengetahui faktor-faktor penyebab terjadinya masalah tersebut. Tingkat pengetahuan dan pendidikan warga Kecamatan Tanjungsari yang rendah tentang pernikahan dini dapat meningkatkan angka kejadian pernikahan dini. Sumber informasi yang kurang juga memungkinkan akan meningkatkan kejadian pernikahan dini. Serta pola asuh orangtua yang memengaruhi pergaualan anak juga dapat meningkatkan kejadian pernikahan dini. Kecamatan Tanjungsari sendiri memiliki karkteristik demografi yang berbeda dengan penelitian-penelitian sebelumnya yang peneliti temukan. Salah satunya adalah penelitian yang dilakukan oleh Habibah (2018) tentang pernikahan dini yang dilakukan di Ciwidey, Bandung dimana di wilayah tersebut terdapat banyak tempat wisata yang selalu dikunjungi oleh wisatawan baik dari dalam ataupun luar wilayah [8]. Berbeda dengan Kecamatan Tanjungsari yang wilayahnya sebagian besar pemukiman warga setempat. Oleh karena itu, peneliti merasa tertarik untuk melakukan penelitian tentang hubungan pengetahuan, tingkat pendidikan, sumber informasi, dan pola asuh dengan pernikahan dini di Kecamatan Tanjungsari, Sumedang.

\section{Metode}

Penelitian ini dilakukan dengan menggunakan jenis penelitian kuantitatif dengan desain deskriptif korelasional dan menggunakan pendekatan case control. Populasi dalam penelitian ini adalah wanita di KecamatanTanjungsari yang telah menikah dan terdaftar di KUA Kecamatan Tanjungsari Kabupaten Sumedang pada bulan Januari-April tahun 2018 sebanyak 344 wanita, menggunakan simple random sampling didapatkan 86 responden, dengan perbandingan case:control adalah 1:1 maka didapatkan sample case 43 wanita dan sample control 43 wanita. Teknik pengumpulan data menggunakan lembar kuesioner yang terdiri dari tiga bagian yaitu kuesioner data demografi, pengetahuan tentang pernikahan dini [8], dan Parental Authority Questionnaire dan dilakukan secara door to door (peneliti mendatangi responden di tempat tinggal responden).Analisis data menggunakan analisis univariat untuk menggambarkan masing-masing variabel penelitian, dan analisis bivariat untuk melihat hubungan antara variabel dependen dan variabel independen [9].

\section{Hasil dan Diskusi}

Tabel 1. Distribusi Frekuensi Demografi Responden (n=86)

\begin{tabular}{ccc}
\hline Karakteristik & $\boldsymbol{f}$ & $\boldsymbol{\%}$ \\
\hline Usia Saat Menikah & & \\
Menikah Dini ( $\leq 20$ tahun) & 43 & 50 \\
Tidak Menikah Dini (>20 tahun) & 43 & 50 \\
\hline Agama & & \\
Islam & 86 & 100 \\
Paparan Informasi & & \\
Mendapat Informasi & 41 & 47,7 \\
Tidak Mendapat Informasi & 45 & 53,3 \\
Sumber Informasi & & \\
Orang Tua & 7 & 8,1 \\
Guru & 6 & 7,0 \\
Petugas Kesehatan & 3 & 3,5 \\
Televisi & 3 & 3,5 \\
Internet & 22 & 25,6 \\
Tidak ada & 45 & 52,3 \\
\hline
\end{tabular}


Berdasarkan tabel 1 dari 86 responden, 50\% responden menikah dini. Sebagian besar responden memiliki karakteristik yaitu beragama Islam (100\%), tidak memiliki sumber informasi $(52,3 \%)$.

Tabel 2. Pengetahuan Responden tentang Pernikahan Dini $(n=86)$

\begin{tabular}{lcccccc}
\hline \multirow{2}{*}{ Pengetahuan } & \multirow{2}{*}{$\boldsymbol{f}$} & \multirow{2}{*}{} & \multicolumn{2}{c}{ Menikah Dini } & \multicolumn{2}{c}{ Tidak Menikah Dini } \\
\cline { 5 - 7 } & & & $\boldsymbol{f}$ & $\boldsymbol{\%}$ & $\boldsymbol{f}$ & $\boldsymbol{\%}$ \\
\hline Baik & 33 & 38,4 & 1 & 3,0 & 32 & 97,0 \\
Buruk & 52 & 61,6 & 42 & 79,2 & 11 & 20,8 \\
\hline
\end{tabular}

Berdasarkan tabel 2 di atas, dapat dilihat bahwa dari 86 responden, sebagian besar responden memiliki pengetahuan yang buruk $(61,6 \%)$. Responden dengan pengetahuan buruk sebagian besar menikah dini $(79,2 \%)$. Sedangkan responden dengan pengetahuan baik sebagian besar tidak melakukan pernikahan dini $(97,0 \%)$.

Tabel 3. Pendidikan Responden ( $\mathrm{n}=86)$

\begin{tabular}{|c|c|c|c|c|c|c|}
\hline \multirow{2}{*}{ Pendidikan } & \multirow{2}{*}{$f$} & \multirow{2}{*}{$\%$} & \multicolumn{2}{|c|}{ Menikah Dini } & \multicolumn{2}{|c|}{ Tidak Menikah Dini } \\
\hline & & & $f$ & $\%$ & $f$ & $\%$ \\
\hline Tidak Tamat SD & 4 & 4,7 & 4 & 100 & 0 & 0 \\
\hline SD & 20 & 23,3 & 18 & 90 & 2 & 10 \\
\hline SMP & 26 & 30,2 & 19 & 73,1 & 7 & 26,9 \\
\hline SMA & 28 & 32,6 & 2 & 7,1 & 26 & 92,9 \\
\hline Perguruan Tinggi & 8 & 9,3 & 0 & 0 & 8 & 100 \\
\hline
\end{tabular}

Berdasarkan tabel 3 di atas, dapat dilihat bahwa sebagian besar responden memiliki pendidikan SMA $(32,6 \%)$, sedangkan sebagian kecil memiliki pendidikan Tidak Tamat SD (4,7\%). Responden dengan pendidikan SMA sebagian besar tidak menikah dini $(92,9 \%)$. Responden dengan pendidikan SMP sebagian besar menikah dini $(73,1 \%)$. Responden dengan pendidikan SD sebagian besar menikah dini (90\%). Responden dengan pendidikan Tidak Tamat SD seluruhnya menikah dini. Responden dengan pendidikan Perguruan Tinggi seluruhnya tidak menikah dini.

Tabel 4. Sumber Informasi tentang Pernikahan Dini pada Responden $(\mathrm{n}=86)$

\begin{tabular}{lllllll}
\hline \multicolumn{1}{c}{ Informasi } & $\boldsymbol{f}$ & $\boldsymbol{\%}$ & \multicolumn{2}{c}{$\begin{array}{c}\text { Menikah } \\
\text { Dini }\end{array}$} & \multicolumn{2}{c}{$\begin{array}{c}\text { Tidak } \\
\text { Menikah } \\
\text { Dini }\end{array}$} \\
\cline { 4 - 7 } & & & $\boldsymbol{f}$ & $\boldsymbol{\%}$ & \multicolumn{1}{c}{$\boldsymbol{f}$} & $\%$ \\
\hline PaparanInformasi & & & & & & \\
Ya & 41 & 47,7 & 6 & 14,6 & 35 & 85,4 \\
Tidak & 45 & 52,3 & 37 & 82,2 & 8 & 17,8 \\
Sumber Informasi & & & & & & \\
Orang tua & & & & & & \\
Guru & 7 & 8,1 & 3 & 42,9 & 4 & 57,1 \\
Petugaskesehatan & 6 & 7 & 2 & 33,3 & 4 & 66,7 \\
Televisi & 3 & 3,5 & 1 & 33,3 & 2 & 66,7 \\
Internet & 3 & 3,5 & 0 & 0 & 3 & 100 \\
Tidak ada & 22 & 25,6 & 0 & 0 & 22 & 100 \\
& 45 & 52,3 & 37 & 82,2 & 8 & 17,8 \\
\hline
\end{tabular}

Berdasarkan tabel 4 di atas, dapat dilihat bahwa sebagian besar responden tidak terpapar informasi tentang pernikahan dini $(52,3 \%)$, sedangkan sebagian lain terpapar informasi tentang pernikahan dini $(47,7 \%)$. Responden yang tidak terpapar informasi sebagian besar menikah dini $(82,2 \%)$, dan sebagian lain tidak menikah dini $(17,8 \%)$. Sedangkan responden yang terpapar informasi sebagain besar tidak menikah dini $(85,4 \%)$, dan sebagian lain menikah dini $(14,6 \%)$. 
Tabel 5. Pola Asuh pada Responden( $\mathrm{n}=86)$

\begin{tabular}{lcccccc}
\hline \multirow{2}{*}{ Pola Asuh } & \multirow{2}{*}{$\boldsymbol{f}$} & \multirow{2}{*}{} & \multicolumn{3}{c}{ Menikah Dini } & \multicolumn{2}{c}{ Tidak Menikah Dini } \\
\cline { 4 - 7 } & & & $\boldsymbol{f}$ & $\boldsymbol{\%}$ & $\boldsymbol{f}$ & $\boldsymbol{\%}$ \\
\hline Authoritative & 41 & 47,7 & 8 & 19,5 & 33 & 80,5 \\
Authoritarian & 9 & 10,5 & 7 & 77,8 & 2 & 22,2 \\
Permissive & 32 & 37,2 & 28 & 87,5 & 4 & 12,5 \\
Un-differetiated & 4 & 4,7 & 0 & 0 & 4 & 100 \\
\hline
\end{tabular}

Berdasarkan tabel 5 di atas, dapat dilihat bahwa sebagian besar pola asuh responden adalah authoritative (47,7\%). Responden dengan jenis pola asuh authoritative sebagian besar tidak menikah dini $(80,5 \%)$. Responden dengan jenis pola asuh permissive sebagian besar menikah dini (87,5\%). Responden dengan jenis pola asuh authoritarian sebagian besar menikah dini $(77,8 \%)$. Responden dengan jenis pola asuh undifferetiated seluruhnya tidak menikh dini (100\%).

Tabel 6. Hubungan Pengetahuan denganPernikahan Dini( $\mathrm{n}=86)$

\begin{tabular}{|c|c|c|c|c|c|}
\hline \multirow[b]{2}{*}{ Pengetahuan } & \multicolumn{2}{|c|}{ Usia Menikah } & \multirow[b]{2}{*}{$\begin{array}{c}\text { Total } \\
(\%)\end{array}$} & \multirow[b]{2}{*}{$p$} & \multirow[b]{2}{*}{$P R$} \\
\hline & $\begin{array}{l}\text { Dini } \\
(\%)\end{array}$ & $\begin{array}{c}\text { Tidak Dini } \\
(\%)\end{array}$ & & & \\
\hline $\begin{array}{l}\text { Baik } \\
\text { Buruk }\end{array}$ & $\begin{array}{c}3 \\
79,2\end{array}$ & $\begin{array}{c}97 \\
20,8\end{array}$ & $\begin{array}{l}38,4 \\
61,6\end{array}$ &, 000 &, 008 \\
\hline
\end{tabular}

$*$ Correlation coefficient $=-0,741$

Berdasarkan tabel 6 diatas, dapat diketahui bahwa responden yang memililiki pengetahuan baik dan tidak menikah dini sebanyak $97 \%$. Sedangkan responden yang memiliki pengetahuan buruk dan menikah dini sebanyak 79,2\%. Berdasarkan hasil uji statistik diperoleh nilai $(p=0,000<0,005)$ dapat disimpulkan bahwa ada hubungan antara pengetahuan dengan pernikahan dini. Koefisien korelasi antara pengetahuan dan pernikahan dini adalah $-0,741$ yang berarti keduanya memiliki hubungan negatif yaitu apabila memiliki pengetahuan baik maka tidak menikah dini, dan sebaliknya apabila memiliki pengetahuan buruk maka menikah dini. Hasil lain yang didapatkan dari uji statistik adalah nilai $P R$ sebesar 0,008artinya bahwa responden dengan pengetahuan buruk memiliki resiko 0,008 kali untuk menikah dini dibandingkan dengan responden dengan pengetahuan baik.

Tabel 7. Hubungan Tingkat Pendidikan dengan Pernikahan Dini( $\mathrm{n}=86)$

\begin{tabular}{|c|c|c|c|c|c|}
\hline \multirow[b]{2}{*}{ Tingkat Pendidikan } & \multicolumn{2}{|c|}{ Usia Menikah } & \multirow{2}{*}{$\begin{array}{c}\text { Total } \\
(\%)\end{array}$} & \multirow[b]{2}{*}{$p$} & \multirow[b]{2}{*}{$C C$} \\
\hline & $\begin{array}{l}\text { Dini } \\
(\%)\end{array}$ & $\begin{array}{c}\text { Tidak Dini } \\
(\%)\end{array}$ & & & \\
\hline Tidak Tamat SD & 100 & 0 & 4,7 & & \\
\hline SD & 90 & 10 & 23,3 & & \\
\hline SMP & 73,1 & 26,9 & 30,2 & 0,000 & 0,739 \\
\hline SMA & 7,1 & 92,9 & 32,6 & & \\
\hline Perguruan Tinggi & 0 & 100 & 9,3 & & \\
\hline
\end{tabular}

Berdasarkan tabel 7 diatas, dapat diketahui bahwa berdasarkan hasil uji statistik diperoleh nilai $(p=0,000<0,05)$ dapat disimpulkan bahwa ada hubungan antara tingkat pendidikan dengan pernikahan dini. Koefisien korelasi antara pendidikan dan pernikahan dini adalah 0,739 yang berarti keeratan hubungan antara pendidikan dan pernikahan dini di tingkat kuat.

Tabel 8. Hubungan Sumber Informasi dengan Pernikahan Dini( $(\mathrm{n}=86)$

\begin{tabular}{|c|c|c|c|c|c|}
\hline \multirow[b]{2}{*}{$\begin{array}{l}\text { Paparan } \\
\text { Informasi }\end{array}$} & \multicolumn{2}{|c|}{ Usia Menikah } & \multirow[b]{2}{*}{$\begin{array}{c}\text { Total } \\
(\%)\end{array}$} & \multirow[b]{2}{*}{$p$} & \multirow[b]{2}{*}{$P R$} \\
\hline & $\begin{array}{l}\text { Dini } \\
(\%)\end{array}$ & $\begin{array}{c}\text { Tidak Dini } \\
(\%)\end{array}$ & & & \\
\hline $\mathrm{Ya}$ & 14,6 & 85,4 & 47,7 & \multirow{2}{*}{, 000} & \multirow{2}{*}{,037 } \\
\hline Tidak & 82,2 & 17,8 & 52,3 & & \\
\hline
\end{tabular}


Berdasarkan tabel 8 diatas, dapat diketahui bahwa responden yang mendapat sumber informasi tentang pernikahan dini dan tidak menikah dini sebanyak $85,4 \%$. Sedangkan responden yang tidak mendapat informasi tentang pernikahan dini dan menikah dini sebanyak $82,2 \%$. Berdasarkan hasil uji statistik diperoleh nilai $(p=0,000<0,005)$ dapat disimpulkan bahwa ada hubungan antara sumber informasi dengan pernikahan dini. Koefisien korelasi antara sumber informasi dan pernikahan dini adalah $-0,675$ yang berarti keduanya memiliki hubungan negatif yaitu apabila mendapat sumber informasi maka tidak menikah dini, dan sebaliknya apabila tidak mendapat sumber informasi maka menikah dini. Hasil lain yang didapatkan dari uji statistik adalah nilai $P R$ sebesar 0,037 artinya bahwa responden yang tidak mendapat informasi tentang pernikahan dini memiliki resiko 0,037 kali untuk menikah dini dibandingkan dengan responden yang mendapat informasi tentang pernikahan dini.

Tabel 9. Hubungan Pola Asuh dengan Pernikahan Dini( $\mathrm{n}=86)$

\begin{tabular}{|c|c|c|c|c|c|}
\hline & \multicolumn{2}{|c|}{ Usia Menikah } & \multirow[b]{2}{*}{$\begin{array}{c}\text { Total } \\
(f)\end{array}$} & \multirow[b]{2}{*}{$P$} & \multirow[b]{2}{*}{$C C$} \\
\hline & $\begin{array}{c}\text { Dini } \\
(f)\end{array}$ & $\begin{array}{l}\text { Tidak Dini } \\
(f)\end{array}$ & & & \\
\hline \multirow{2}{*}{$\begin{array}{l}\text { Authoritative } \\
\quad \text { Non-authoritative }\end{array}$} & 8 & 33 & 41 & \multirow{2}{*}{, 000} & \multirow{2}{*}{, 503} \\
\hline & 35 & 10 & 45 & & \\
\hline Authoritarian & 7 & 2 & 9 & \multirow{2}{*}{,078 } & \multirow{2}{*}{, 187} \\
\hline Non-authoritarian & 36 & 41 & 77 & & \\
\hline Permissive & 28 & 4 & 32 & \multirow{2}{*}{,000 } & \multirow{2}{*}{, 500} \\
\hline Non-permisssive & 15 & 39 & 54 & & \\
\hline Undifferetiated & 0 & 4 & 4 & \multirow{2}{*}{,041 } & \multirow{2}{*}{,216 } \\
\hline Non-undifferetiated & 43 & 39 & 82 & & \\
\hline
\end{tabular}

Berdasarkan tabel 9 diatas, dapat dilihat secara keseluruhan bahwa berdasarkan uji stastistik di dapatkan hasil nilai $(p=0,000<0,05)$ yang berarti ada hubungan antara pola asuh dengan pernikahan dini, dan nilai koefisien korelasi sebesar 0,564 sehingga dapat diketahui keeratan hubungan antara pola asuh dan pernikahan dini di tingkat sedang.

Sebanyak 45 responden yang memiliki pola asuh authoritative, sebagian besar reponden tidak menikah dini yaitu 33 responden. Berdasarkan hasil uji statistik chi-square di dapatkan nilai $(p=0,000<0,05)$ yang berarti ada hubungan antara pola asuh authoritative dengan pernikahan dini, dan nilai koefisien kontingensi sebesar 0,503 sehingga dapat diketahui keeratan hubungan antara pola asuh authoritative dengan pernikahan dini di tingkat sedang.

Sebanyak 9 responden yang memiliki pola asuh authoritarian, sebagian besar reponden tidak menikah dini yaitu sebanyak 7 responden. Berdasarkan hasil uji statistik chi-square di dapatkan nilai $(p=0,078>0,05)$ yang berarti tidak ada hubungan antara pola asuh authoritarian dengan pernikahan dini.

Sebanyak 32 responden yang memiliki pola asuh permissive, 28 responden menikah dini dan 4 reponden tidak menikah dini. Berdasarkan hasil uji statistik chi-square di dapatkan nilai $(p=0,000<0,05)$ yang berarti ada hubungan antara pola asuh permissive dengan pernikahan dini, dan nilai koefisien kontingensi sebesar 0,500 sehingga dapat diketahui keeratan hubungan antara pola asuh permissive dengan pernikahan dini di tingkat sedang.

Sebanyak 4 responden yang memiliki pola asuh undifferetiated, seluruhnya tidak menikah dini. Berdasarkan hasil uji statistik chi-square di dapatkan nilai $(p=0,048<0,05)$ yang berarti ada hubungan antara pola asuh undifferetiated dengan pernikahan dini, dan nilai koefisien kontingensi sebesar 0,216 sehingga dapat diketahui keeratan hubungan antara pola asuh undifferetiated dengan pernikahan dini di tingkat rendah.

\section{Pembahasan}

Hasil penelitian menunjukkan terdapat beberapa faktor yang mempengaruhi pernikahan dini di Kecamatan Tanjungsari, Sumedang diantaranya pengetahuan, tingkat pendidikan, sumber informasi, dan pola asuh. Hal tersebut dapat diketahui dengan melihat hasil penelitian bahwa sebagian besar wanita yang menikah dini di Kecamatan Tanjungsari memiliki pengetahuan yang 
buruk tentang pernikahan dini, tingkat pendidikan yang rendah, tidak pernah mendapatkan informasi tentang pernikahan dini, juga mendapatkan pola asuh permissive dari orang tua responden.

Berdasarkan hasil penelitian, sebagian besar responden yang menikah dini memiliki pengetahuan yang buruk tentang pernikahan dini. Hal ini dikarenakan responden yang memiliki pengetahuan baik tentang pernikahan dini akan mengerti dan paham dampak dari pernikahan dini yang mana lebih banyak berdampak negatif bagi wanita. Sehingga responden dengan pengetahuan yang baik akan menghindari pernikahan dini. Hasil dari uji statistik antara variabel pengetahuan dan pernikahan dini didapatkan bahwa ada hubungan yang bersifat negatif antara pengetahuan dengan pernikahan dini, yaitu apabila responden memiliki pengetahuan yang baik tentang pernikahan dini, maka responden tidak menikah dini. Dan sebaliknya, apabila responden memiliki pengetahuan yang buruk tentang pernikahan dini, maka responden menikah dini. Hasil lainnya yaitu responden dengan pengetahuan yang buruk memiliki resiko 0,008 kali untuk menikah dini dibandingkan dengan responden dengan pengetahuan baik. Hasil ini sejalan dengan penelitian Stang(2015) dan Desiyanti(2015) yang menyatakan bahwa terdapat hubungan antara pegetahuan dengan pernikahan dini [3][6].

Hasil lain dari penelitian ini menyatakan bahwa semakin rendah pendidikan responden, maka cenderung akan melakukan pernikahan dini. Hal ini kemungkinan terjadi karena responden dengan tingkat pendidikan rendah cenderung sulit untuk menerima informasi. Hasil uji statistik antara variabel tingkat pendidikan dan pernikahan dini didapatkan bahwa ada hubungan antara tingkat pendidikan dan pernikahan dini dengan keeratan hubungan di tingkat kuat. Hasil penelitian ini sejalan dengan penelitian yang dilakukan oleh Desiyanti(2015) dan Hotchkiss et al.(2016) yang menyatakan bahwa ada hubungan antara tingkat pendidikan dengan pernikahan dini [6][10].

Dari penelitian ini juga dihasilkan bahwa sebagian besar responden yang menikah dini tidak pernah terpapar informasi tentang pernikahan dini. Hal ini terjadi karena responden yang tidak terpapar informasi tentang pernikahan dini tidak mengetahui bahwa terdapat berbagai dampak negatif apabila melakukan pernikahan dini, sehingga menganggap bahwa pernikahan merupakan hal yang sederhana dan dapat dijalani oleh siapapun tanpa hambatan. Hasil uji statistik antara variabel sumber informasi dan pernikahan dini menyatakan bahwa ada hubungan yang bersifat negatif antara sumber informasi dengan pernikahan dini, yaitu apabila responden terpapar informasi tentang pernikahan dini maka responden tidak menikah dini. Dan sebaliknya, apabila tidak terpapar informasi tentang pernikahan dini maka responden akan menikah dini. Responden yang tidak terpapar informasi memiliki resiko sebesar 0,037 kali untuk menikah dini dibandingkan dengan responden yang tidak terpapar informasi. Dalam hal ini, peneliti tidak menemukan penelitian sebelumnya yang membahas hubungan antara sumber informasi dengan pernikahan dini. Namun, hasil ini sejalan dengan pernyataan WHO yaitu pernikahan dini dan kehamilan beresiko tinggi terjadi karena kurangnya informasi mengenai kesehatan reproduksi. Hal tersebut juga sebanding dengan penelitian yang dilakukan oleh Ikutwa(2015) yang mengatakan bahwa sumber informasi yang kurang akan mempengaruhi pengetahuan responden tentang kesehatan dirinya sendiri, baik kesehatan mental maupun fisik [11].

Hasil penelitian lainnya yaitu ada hubungan antara pola asuh dengan pernikahan dini dengan keeratan hubungan di tingkat sedang. Jenis pola asuh yang paling memengaruhi pernikahan dini yaitu pola asuh permissive, yang mana dari hasil uji statistik dinyatakan bahwa terdapat hubungan antara pola asuh permissive dengan pernikahan dini dengan keeratan hubungan di tingkat sedang. Hal ini terjadi karena pola asuh permissive sendiri merupakan pola asuh dimana orang tua memberikan kebebasan pada anak untuk mengambil keputusan sendiri. 
Sehingga sebagian besar responden dengan pola asuh permissive cenderung mengikuti lingkungan dimana menikah lebih cepat dianggap lebih baik. Sedangkan jenis pola asuh dengan sebagian besar responden tidak menikah dini yaitu pola asuh authoritative.Hal ini terjadi karena pola asuh authoritative sendiri merupakan pola asuh dimana orang tua selalu memberikan arahan kepada anak, namun orang tua juga secara terbuka mau menerima pendapat anak dan mendiskusikannya bersama untuk mendapatkan keputusan yang terbaik bagi anak. Sehingga responden dengan pola asuh authoriative cenderung akan memiliki tujuan hidup yang lebih baik karena adanya arahan dan keterbukaan orang tua dalam mengambil suatu keputusan. Hasil penelitian ini sejalan dengan penelitian yang dilakukan oleh Purwaningsih \& Setyaningsih (2014) yang menyatakan bahwa terdapat hubungan antara pola asuh dengan pernikahan dini, yang mana jenis pola asuh yang paling memengaruhi pernikahan dini adalah pola asuh permissive. Untuk pola asuh authorian, didapatkan hasil bahwa tidak ada hubungan antara pola asuh authoritarian dengan pernikahan dini. Hal ini berbanding terbalik dengan penelitian sebelumnya yang menyatakan bahwa pada pola asuh ini biasanya anak diawasi ketat oleh otangtua sehingga pernikahan dini tidak terjadi. Namun, pada penelitian ini justru responden dengan pola asuh authoritarian sebagian besar melakukan pernikahan dini. Hal ini terjadi karena pola asuh authoritarian merupakan pola asuh dimana orang tua memaksa anak untuk selalu menuruti apa yang orang tua katakan, yang mana responden dengan pola asuh authoritarian dalam penelitian ini sebagian besar menikah din karena keinginan orangtua. Sehingga responden tidak bisa menolak saat dijodohkan oleh orang tua [12].

\section{Kesimpulan}

Berdasarkan hasil penelitian yang membahas tentang pernikahan dini pada wanita di Kecamatan Tanjungsari, Sumedang dapat disimpulkan bahwa ada hubungan antara pengetahuan, tingkat pendidikan, sumber informasi, dan pola asuh dengan pernikahan dini pada wanita di Kecamatan Tanjungsari, Sumedang.

\section{Referensi}

[1] BPS. (2016). Analisis Data Perkawinan Usia Anak di Indonesia.. https://doi.org/978-978-064963-6.

[2] Baumrind, D. (2012). Effects of Authoritative Parental Control on Child Behavior. Child Development, 37(4), 887-907.

[3] Stang. (2015). Faktor-Faktor yang Berhubungan dengan Pernikahan Dini di Kelurahan Pangli Kecamatan Sesean Kabupaten Toraja Utara. Jurnal MKMI.

[4] Karim, A., \& Prasetyo, C. (2017). Faktor-faktor Penyebab Terjadinya Pernikahan Usia Dini di Kelurahan Beji Kecamatan Ungaran Timur Kabupaten Semarang. SNHP, 123-128.

[5] Rusmono, D. (2018). Filsafat ilmu - Pengetahuan dan Ilmu Pengetahuan, (August).

[6] Desiyanti, I.W. (2015). Faktor-Faktor yang Berhubungan Terhadap Pernikahan Dini Pada Pasangan Usia Subur di Kecamatan Mapanget Kota Manado. Jikmu, 5, 270-280.

[7] Nur, A. S., Mberia, H., \& Muturi, W. (2016). Role of Socio Economic Factors on Early Marriage Practices in Garowe District. European Journal of Business and Social Sciences, 5(09), 33-48. Retrieved from http://www.ejbss.com/Data/Sites/1/vol5no09 december2016/ejbss-1826-16-roleofsocioeconomic

[8] Habibah, N. (2017). Pengetahuan, Sikap dan Nilai-nilai Budaya Remaja Terhadap Pernikahan Dini di SMP Negeri 1 Rancabali Kabupaten Bandung.

[9] Buri, J. R. (1991). Parental Authority Questionnaire Instructions: Journal of Personality, 1113.

[10] Hotchkiss, D.R., Godha, D., Gage, A. J., \& Cappa, C. (2016). Risk Factors Associated with The Practice of Child Marriage Among Roma Girls in Serbia. BMC International Health and Human Rights, 1-10. https://doi.org/10.1186/s12914-016-0081-3 
[11] Ikutwa, N. L. (2015). Factors Influencing Early Marriage On The Girl Child's Maternal Health Projects: A Case Of Maralal Town, Samburu County, Kenya.

[12] Purwaningsih, E., \& Setyaningsih, R. T. (2014). Hubungan Pola Asuh Orang Tua Dengan Kejadian Pernikahan Usia Dini Di Desa Jambu Kidul, Ceper, Klaten. Jurnal Involusi Kebidanan, 4(7), 1-12. 